\title{
Inventarisasi Belalang (Orthoptera: Acrididae) di Perkebunan dan Persawahan Desa Serdang Menang, Kecamatan Sirah Pulau Padang, Kabupaten Ogan Komering Ilir
}

\author{
Ari Sugiarto \\ Email: sugiartoari13@gmail.com
}

\begin{abstract}
Abstrak
Belalang (Orthoptera: Acrididae) dapat menjadi ancaman pada tanaman pertanian. Desa Serdang Menang memiliki ekosistem perkebunan dan persawahan yang memiliki potensi acaman dari belalang. Perlu dilakukan inventarisasi belalang (Orthoptera: Acrididae) di perkebunan dan persawahan Desa Serdang Menang sebagai upaya perkiraan potensi acaman dari belalang pada ekosistem perkebunan dan persawahan. Penelitian ini dilakukan di perkebunan dan persawahan Desa Serdang Menang, Kecamatan Sirah Pulau Padang, Kabupaten Ogan Komering Ilir pada bulan Oktober 2018. Metode penelitian ini dengan menggunakan Sweep net and hand picking, serta pengambilan foto belalang dengan camera. Spesies belalang (Orthoptera: Acrididae) yang ditemukan di ekosistem perkebunan dan persawahan Desa Serdang Menang berjumlah 6 spesies (Gesonula mundata, Oxya Hyla, Phlaeoba fumosa, Traulia azureipennis, Valanga nigricornis, dan Xenocatantops humilis). Spesies belalang lebih banyak ditemukan pada ekosistem persawahan dibanding pada ekosistem perkebunan, hal ini dapat menunjukkan bahwa pada ekosistem persawahan memiliki potensi ancaman belalang yang lebih besar dibanding pada ekosistem perkebunan.
\end{abstract}

Kata Kunci: Belalang (Orthoptera: Acrididae), Ekosistem, Desa Serdang Menang

\section{Pendahuluan}

Belalang termasuk dalam ordo Orthoptera dengan jumlah species diperkirakan berjumlah 20.000 (Borror et al., 2005 dalam Prakoso, 2017). Belalang tidak terdistribusi secara acak pada lingkungan yang berbeda dimana mereka berada. Belalang memiliki pola distribusi yang terkait terutama dengan ketersediaan makan pada berbagai jenis vegetasi, faktor antropik, jumlah cahaya dan bayangan (Almeida dan Camara, 2008).

Salah satu famili dari ordo Orthoptera adalah Acrididae. Menurut Seino et al. (2013), belalang antena pendek dari famili Acrididae merupakan hama pada tanaman pertanian. Hal ini juga didukung oleh Prakoso (2017), belalang dari famili Acrididae berperan sebagai herbivora pada pada ekosistem.

Desa Serdang Menang yang terletak di Kecamatan Sirah Pulau Padang, Kabupaten
Ogan Komering Ilir terdiri dari beberapa ekosistem yaitu ekosistem Perkebunan, Persawahan, Sungai, dan Permukiman. Melihat peran belalang pada ekosistem yang cendrung merugikan, perlu dilakukan inventarisasi belalang di perkebunan dan persawahan Desa Serdang Menang dalam upaya perkiraan potensi acaman dari belalang pada ekosistem perkebunan dan persawahan.

\section{Metode Penelitian}

Penelitian ini dilakukan di Desa Serdang Menang, Kecamatan Sirah Pulau Padang, Kabupaten Ogan Komering Ilir pada bulan Oktober 2018. Lokasi sampling ditentukan pada ekosistem perkebunan dan persawahan. Berdasarkan penelitian Almeida dan Camara (2008), belalang ditemukan pada berbagai jenis vegetasi. Pengambilan sampel belalang dilakukan 
dengan menggunakan Sweep net and hand picking (Seino et al., 2013). Belalang yang sudah diidentifikasi kemudian dilepaskan kembali (Parches et al., 2010). Selain menangkap belalang dengan Sweep net and hand picking juga dilakukan pengambilan foto belalang dengan camera. Identifikasi spesies belalang yang didapatkan dilakukan dengan mencokkan dengan gambar belalang yang sudah teridentifikasi spesiesnya.

\section{Hasil dan Pembahasan}

Berdasarkan penelitian yang telah dilakukan didapatkan hasil spesies belalang di ekosistem perkebunan dan persawahan Desa Serdang Menang, Kecamatan Sirah Pulau Padang, Kabupaten Ogan Komering Ilir yaitu:

Tabel 1. Spesies belalang (Orthoptera: Acrididae) di ekosistem perkebunan dan persawahan Desa Serdang Menang, Kecamatan Sirah Pulau Padang, Kabupaten Ogan Komering Ilir

\begin{tabular}{lll}
\hline Famili & Genus & Spesies \\
\hline Acrididae & Gesonula & Gesonula mundata \\
Oxya & Oxya Hyla \\
Phlaeoba & Phlaeoba fumosa \\
Traulia & Traulia azureipennis \\
Valanga & Valanga nigricornis \\
Xenocatantops & Xenocatantops humilis
\end{tabular}

Spesies belalang (Orthoptera: Acrididae) yang ditemukan di ekosistem perkebunan dan persawahan Desa Serdang Menang berjumlah 6 spesies (Gesonula mundata, Oxya Hyla, Phlaeoba fumosa, Traulia azureipennis, Valanga nigricornis, dan Xenocatantops humilis) yang terdiri dari 5 genus (Gesonula, Oxya, Phlaeoba, Valanga, dan Xenocatantops). Belalang (Orthoptera: Acrididae) paling banyak ditemukan pada ekosistem persawahan yang banyak memiliki vegetasi semak, rumput, dan perdu. Spesies Gesonula mundata, Oxya Hyla, Xenocatantops humilis dapat ditemukan dengan mudah pada ekosistem perswahan ini. Spesies Traulia azureipennis ditemukan pada ekosistem perkebunan dan tidak ditemukan pada ekosistem persawahan.

Menurut Almeida dan Camara (2008), tipe vegetasi pada suatu ekosistem mempengaruhi keberadaan species belalang pada ekosistem tersebut. Hal ini didukung oleh Prakoso (2017), spesies belalang akan lebih banyak pada ekosistem yang memiliki keanekaragaman flora yang tinggi.

Berlebihnya populasi belalang (Orthoptera: Acrididae) pada ekosistem perkebunan dan persawahan, tentunya memperbesar potensi gangguan pada ekosistem tersebut. Menurut Seino et al. (2013), belalang antena pendek dari famili Acrididae merupakan hama pada tanaman pertanian. Hal ini juga didukung oleh Prakoso (2017), belalang dari famili Acrididae berperan sebagai herbivora pada pada ekosistem.

Keanekargaman yang tinggi pada suatu ekosistem tentunya dapat menilai ekosistem tersebut masih terjaga kelestariannya. Menurut Seino et al. (2013), belalang memiliki kepekaan terhadap gangguan yang membuat mereka dapat dijadikan bioindikator potensial yang berguna untuk pengelolaan lahan. 


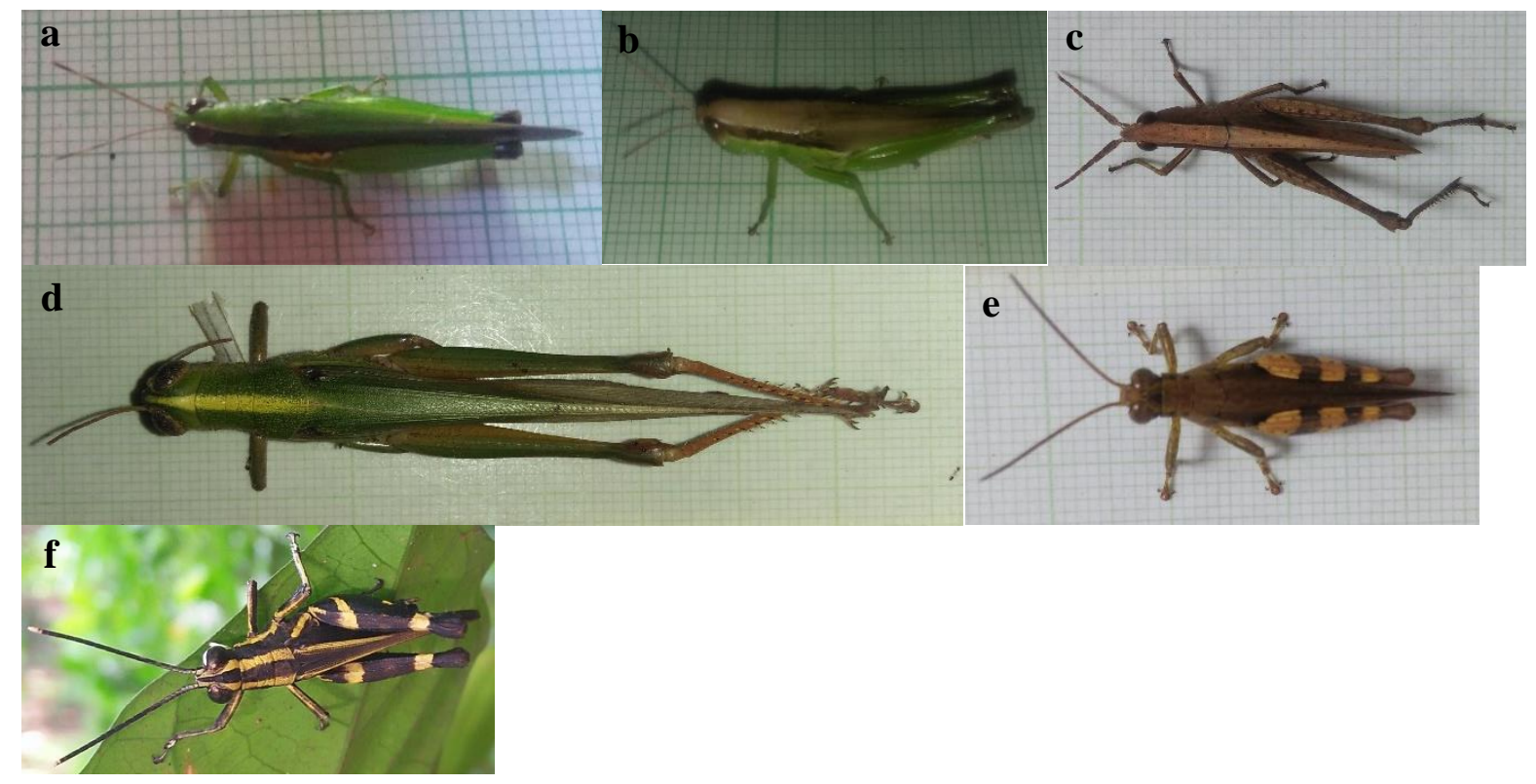

Gambar 1. a. Gesonula mundata, b. Oxya Hyla, c. Phlaeoba fumosa, d. Valanga nigricornis, e. Xenocatantops humilis, f. Traulia azureipennis

Tabel 2. Spesies belalang (Orthoptera: Gryllidae, Pyrgomorphidae, Tettigoniidae) yang tertangkap di ekosistem perkebunan dan persawahan Desa Serdang Menang, Kecamatan Sirah Pulau Padang, Kabupaten Ogan Komering Ilir

\begin{tabular}{lll}
\hline Famili & Genus & Spesies \\
\hline Gryllidae & Euscyrtus & Euscyrtus concinus \\
\hline Pyrgomorphidae & Atractomorpha & $\begin{array}{l}\text { Atractomorpha } \text { crenulata } \\
\text { Atractomorpha } \text { sp. }\end{array}$ \\
\hline Tettigoniidae & Hecacentrus & $\begin{array}{l}\text { Hecacentrus } \text { unicolor } \\
\text { Hecacentrus } \text { sp. }\end{array}$ \\
\hline
\end{tabular}

Spesies belalang (Orthoptera: Gryllidae, Pyrgomorphidae, Tettigoniidae) yang tertangkap di ekosistem perkebunan dan persawahan Desa Serdang Menang terdiri dari 5 spesies (Euscyrtus concinus, Atractomorpha crenulata, Atractomorpha sp., Hecacentrus unicolor, dan Hecacentrus sp.) dari total 3 genus (Euscyrtus, Atractomorpha, dan Hecacentrus). Spesies belalang (Orthoptera: Gryllidae, Pyrgomorphidae, Tettigoniidae) lebih banyak ditemukan pada ekosistem persawahan dibanding pada ekosistem perkebunan. Diperkirakan spesies belalang (Orthoptera: Gryllidae, Pyrgomorphidae, Tettigoniidae) di ekosistem perkebunan dan persawahan jumlahnya jauh lebih banyak dibanding belalang yang tertangkap. Berdasarkan penelitian Walter et al. (2004), adanya area ekologis pada kawasan pertanian akan meningkatkan area distribusi dari belalang pada satu wilayah.

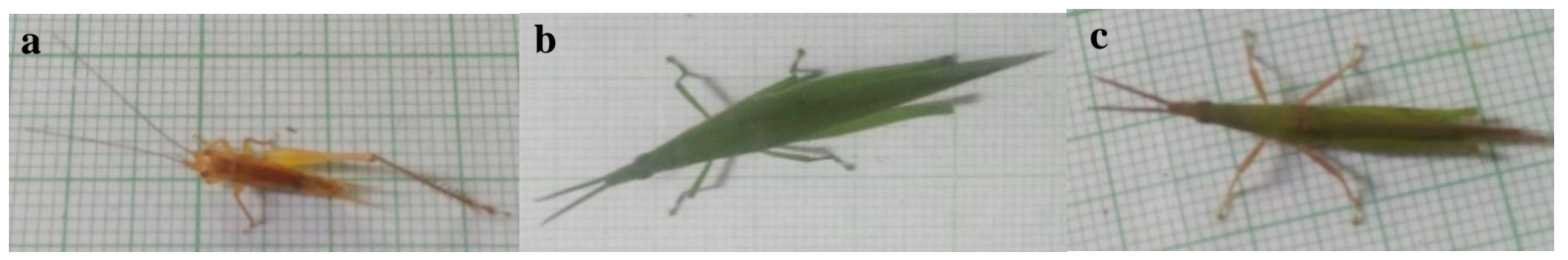




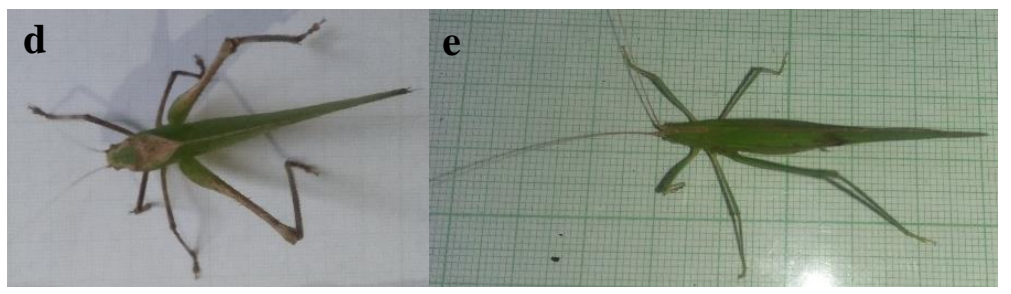

Gambar 2. a. Euscyrtus concinus, b. Atractomorpha crenulata, c. Atractomorpha sp., d. Hecacentrus unicolor, e. Hecacentrus sp.

\section{Kesimpulan}

Berdasarkan penelitian yang telah dilakukan didapatkan kesimpulan spesies belalang (Orthoptera: Acrididae) lebih banyak ditemukan pada ekosistem persawahan dibanding pada ekosistem perkebunan, hal ini dapat menunjukkan bahwa pada ekosistem persawahan memiliki potensi ancaman belalang yang lebih besar dibanding pada ekosistem perkebunan.

\section{Daftar Pustaka}

Almeida, A.V dan Camara, C.A.G. 2008. Distribution of Grasshoppers (Othoptera: Acridoidea) in The Tapacurá Ecological Station (São Lourenço da Mata, PE / Brazil). Braz. J. Biol. 68(1): 2124.

Borror, D.J., Triplehor, N., and Johnson, N.F. 2005. Study of Insect.Ed-7. Amerika: Thomson Brook/Cole. Dalam. Prakoso, B. 2017. Biodiversitas Belalang (Acrididae: ordo Orthoptera) pada Agroekosistem (zea mays L.) dan Ekosistem Hutan Tanaman di Kebun Raya Baturaden, Banyumas. Biosfera. 34(2): 80-88.

Pascher, K., Dietmar, M., Leopold, S., Helmut, H., Norbert, S., Stefen, D., Andreas, T., dan Thomas, F. 2010. Field Guide for a Biodiversity Inventory in The Agrarian Region. Jerman: Bundesministerium für Gesundheit.
Prakoso, B. 2017. Biodiversitas Belalang (Acrididae: ordo Orthoptera) pada Agroekosistem (zea mays L.) dan Ekosistem Hutan Tanaman di Kebun Raya Baturaden, Banyumas. Biosfera. 34(2): 80-88.

Seino, R.A., Dongmo,T.I., Kekeunou, S., Chifon, R.N., dan Manjeli, Y. An inventory of short horn grasshoppers in the Menoua Division, West Region of Cameroon. Agriculture and Biology Journal of North America. 4(3): 291-299.

Walter, T., Hunziker, M., Peter, B., dan Ward, P. 2004. Threatened Grasshopper Species Profit from Ecological Compensation Areas. Grassland Science in Europe. 9(1): 234-236. 